\title{
Cucolepis cincta gen. n. et sp. n. (Cestoda: Cyclophyllidea) from the squirrel cuckoo Piaya cayana Lesson (Aves: Cuculiformes) from Paraguay
}

\author{
Anna J. Phillips ${ }^{1}$, Jean Mariaux ${ }^{2}$ and Boyko B. Georgiev ${ }^{3}$ \\ ${ }^{1}$ Department of Ecology and Evolutionary Biology, University of Connecticut, 75 N. Eagleville Road, Storrs, CT 06269-3043, USA; \\ ${ }^{2}$ Muséum d'Histoire Naturelle de Genève, CP 6434, 1211 Genève 6, Switzerland; \\ ${ }^{3}$ Institute of Biodiversity and Ecosystem Research, Bulgarian Academy of Sciences, 2 Gagarin Street, 1113 Sofia, Bulgaria
}

\begin{abstract}
Cucolepis gen. n. is erected as monotypic for Cucolepis cincta sp. n., a new species of cyclophyllidean cestode of the family Paruterinidae. The new species is described from the squirrel cuckoo, Piaya cayana Lesson (Aves: Cuculiformes), taken from two localities in Paraguay in 1984 and 1985. This new genus is most similar to the genus Triaenorhina Spasskii et Shumilo, 1965 in terms of the hook morphology and large epiphyseal structures extending from both the handle and guard, but differs in several aspects of the strobilar morphology, such as the shape of the cirrus sac, genital atrium, uterus and paruterine organ. The strobilar morphology of the new genus strongly resembles that of the genus Francobona Georgiev et Kornyushin, 1994, especially the shape of the cirrus sac and genital atrium, yet Francobona spp. lack the developed epiphyseal structures observed in species of Cucolepis and Triaenorhina. Previous records and the nature of parasite-host associations between cuculiform birds and their cestode parasites are discussed.
\end{abstract}

Keywords: Cestoda, Paruterinidae, Neotropical, Piaya, new genus, cuckoo

The examination of unidentified avian cestode material from the Muséum d'Histoire Naturelle, Geneva, Switzerland (MHNG), collected from two localities in Paraguay in 1984 and 1985 by either Carlos Dlouhy or Claude Vaucher, revealed the presence of an undescribed genus and species from two squirrel cuckoos, Piaya cayana Lesson. This new genus and its only known species are described below.

\section{MATERIALS AND METHODS}

The material studied consisted of five specimens with scoleces and five fragments of strobila from the squirrel cuckoo, Piaya cayana, collected from Road Stroesner (Road \#7), 230 km from Asunción, Caaguazú, Paraguay, on 13 August 1984, and from near the stream Tagatjia Guazu, $4 \mathrm{~km}$ south of the ranch Santa Maria, Concepción, Paraguay, on 20 October 1985. Specimens were deposited in the collections of invertebrates of the Muséum d'Histoire Naturelle, Geneva, Switzerland (MHNG). All specimens were stained with hydrochloric carmine and mounted in Canada balsam. Measurements were taken using an optical retical or a SPOT Diagnostic Instrument digital camera system mounted on a Zeiss Axioskop 2 (Zeiss, Thornwood, NY) and SPOT software (version 4.5; http://www. diaginc.com/software/). Measurements of the testes, cirrus sac, vitellarium, ovary, vagina and seminal receptacle were taken only from fully developed mature proglottides. Metrical and meristic data are presented as the range (min-max), with the mean, standard deviation and the number of measurements or counts taken (n) in parentheses. The measurements given are in micrometres $(\mu \mathrm{m})$ unless otherwise stated. The terms used for the developmental stages of proglottides follow Georgiev and Vaucher (2001). Avian nomenclature follows the IOC World Bird Names (Gill and Donsker 2012).

\section{RESULTS}

Cucolepis gen. $\mathrm{n}$.

Diagnosis. Scolex with cup-shaped, sucker-like rostellum and double crown of numerous rostellar hooks. Epiphysis of rostellar hooks strongly developed, larger or comparable in size with refractive particle ("true hook"), extending from both handle and guard of refractive particle, i.e. rostellar hooks of the rectanguloid type as defined by Spasskii and Shumilo (1965) and Bona and Maffi (1987). Epiphyses of anterior row longer than those of posterior row. Proglottides craspedote, wider than long except gravid (with almost equal length and width or longer than wide). Genital pores alternating. Genital atrium consists of two parts separated by muscular bundles forming a sphincter; its bottom forming thick-walled circular protrusion. Genital ducts pass between osmoregulatory canals. Testes lateral, posterior and dorsal to vitellarium, also sometimes overlapping posterior or lateral margin of ovary. Cirrus sac pyriform, with very thick 
muscular walls, sometimes reaching osmoregulatory canals. Cirrus unarmed. Vas deferens highly coiled; external vas deferens and encircling tissue forming elongate dense agglomerate situated obliquely. Vitellarium median, compact. Ovary fan-shaped. Seminal receptacle fusiform. Vagina opens dorsally to male pore; vaginal copulatory and conductive parts clearly distinguished. Uterus forming one sac. Paruterine organ anterior to uterus, almost conical. Eggs and onchospheres oval. In Cuculiformes of South America.

Type species: Cucolepis cincta $\mathrm{sp} . \mathrm{n}$.

Ety mology: The generic name is derived from the Spanish "cuco" (cuckoo in English), for the host of the new genus, and the Latin suffix -lepis, which means "scale" and is frequently used as a suffix in names of cyclophyllidean genera. The grammatical gender of Cucolepis is feminine.

Remarks. In its possession of a paruterine organ, a scolex with an armed sucker-like rostellum and rectanguloid hooks in two rows with epiphyseal thickenings of the handle and guard, Cucolepis gen. n. is a member of the family Paruterinidae Fuhrmann, 1907 (for the family diagnosis, see Georgiev and Kornyushin 1994). The new genus belongs to the group of 15 genera, which are characterized by armed scoleces. Among them, only $\mathrm{Cu}$ colepis and Triaenorhina Spasskii et Shumilo, 1965 are characterized by the presence of rostellar hooks of rectanguloid type (Spasskii and Shumilo 1965, Bona and Maffi 1984a, 1987, Georgiev and Kornyushin 1994).

Currently, Triaenorhina includes seven species parasitic in birds of the families Coraciidae, Bucorvidae, Bucerotidae and Trogonidae in the Old World (Georgiev and Gibson 2006), all characterized by strongly developed epiphyseal structures of rostellar hooks comprising both handle and guard. However, the species of Triaenorhina exhibit different strobilar morphology, especially their highly elongate and thin-walled cirrus sac (versus pyriform and thick-walled cirrus sac in the new genus), simple genital atrium (versus genital atrium thick-walled circular protrusion at its base in the new species of Cucolepis) and longitudinally elongate lobate uterus associated with almost conical and short paruterine organ (versus compact and rather globular uterus and almost tubular paruterine organ in most of Triaenorhina spp.; see Georgiev and Kornyushin 1994, Georgiev and Gibson 2006).

The new species of Cucolepis is similar to the two species of the genus Francobona Georgiev et Kornyushin, 1994, which are also parasites of cuculiform birds in the New World (Bona and Mafi 1984b, 1985, Georgiev and Kornyushin 1994). The main difference between species of $\mathrm{Cu}$ colepis and Francobona spp. is the presence of rectanguloid rostellar hooks in the former and simple triangular hooks with small rounded epiphyses of the handle in the latter.

The presence of large epiphyses on rostellar hooks is a highly adaptive character allowing the growth of ros- tellar hooks in the intestine of the definitive host; it allows small rostellar hooks developed in metacestodes to achieve much greater size in the definitive host in order to provide more reliable attachment of mature cestodes (Spasskii and Shumilo 1965). The phenomenon of postlarval growth of rostellar hooks is not frequent across the order Cyclophyllidea and is to occur in members of the paruterinid genera Triaenorhina (see Spasskii and Shumilo 1965) and Cucolepis (present study) as well as for the hymenolepidid genus Confluaria Ablasov in Spasskaya, 1966 (e.g., Vasileva et al. 2000) and for some gryporhynchids (e.g., Scholz et al. 2002). Therefore, it should be regarded as an independently developed characteristic in several cestode families. In view of the substantial similarity of the strobilar morphology of Cucolepis and Francobona and the obvious differences with that of Trianorhina, it can be concluded that the presence of huge ephiphyses of the rostellar hooks of the paruterinid genera Cucolepis and Trianorhina should be regarded as a result of convergent evolution.

In addition to its rectanguloid rostellar hooks, $\mathrm{Cu}$ colepis can be distinguished from the remaining armed paruterinid genera by several characters. Its rostellar hooks are arranged in two rows rather than in four rows as in Neyraia Joyeux et Timon-David, 1934; genital ducts passing between osmoregulatory canals rather than ventrally as in Notopentorchis Burt, 1938; genital pores alternating rather than unilateral as in Troguterina Spasskii, 1991; testes posterior or lateral to the female gonads rather than situated in two groups lateral to and over-reaching the female glands as in Cladotaenia Cohn, 1901 and Paruterina Fuhrmann, 1906; a fan-shaped ovary rather than a bi-winged ovary as in Cladotaenia and Paruterina, Sphaeruterina Johnston, 1914 and Neyraia, or compact as in the genera Notopentorchis and Triaenorhina; a developing uterus that forms one sac rather than two sacs as in Biuterina Fuhrmann, 1902, with posterior diverticula as in Spasskyterina Kornyushin, 1989, or reticular as in the genera Parvirostrum Fuhrmann, 1908 or Dictyterina Spasskii in Spasskaya and Spasskii, 1971; a longitudinally elongate paruterine organ approaching a conical shape rather than being transversely elongate at the anterior proglottis margin as in Laterotaenia Fuhrmann, 1906, Culcitella Fuhrmann, 1906, or Matabelea Mettrick, 1963, a thick-walled longitudinal curved tube terminating in a spherical body at the anterior proglottis margin as in Sphaeruterina, or being wider than long as in Notopentorchis; a unicameral paruterine organ rather than bicameral as in Neyraia (for characteristics of the paruterinid genera, see Georgiev and Kornyushin 1994).

On the basis of these comparisons, we believe that none of the known paruterinid genera can harbour the newly-discovered species and therefore propose the new genus Cucolepis. 
Cucolepis cincta sp. n.

Figs. 1, 2

Description. Body ribbon-shaped (Fig. 1A), gradually widening posteriorly, $61 \mathrm{~mm}(\mathrm{n}=1)$ long, consisting of 200 proglottides, maximum width at level of post-mature or pre-gravid proglottides, $703-1072(890 \pm 137, \mathrm{n}=10)$.
Proglottides craspedote; mature and post-mature proglottides wider than long; pre-gravid and gravid proglottides longer than wide. Scolex rounded (Fig. 1B), with cylindrical apical portion bearing rostellum; maximum width of scolex at mid-level of suckers, $264-360(305 \pm 41, n=5)$.
A

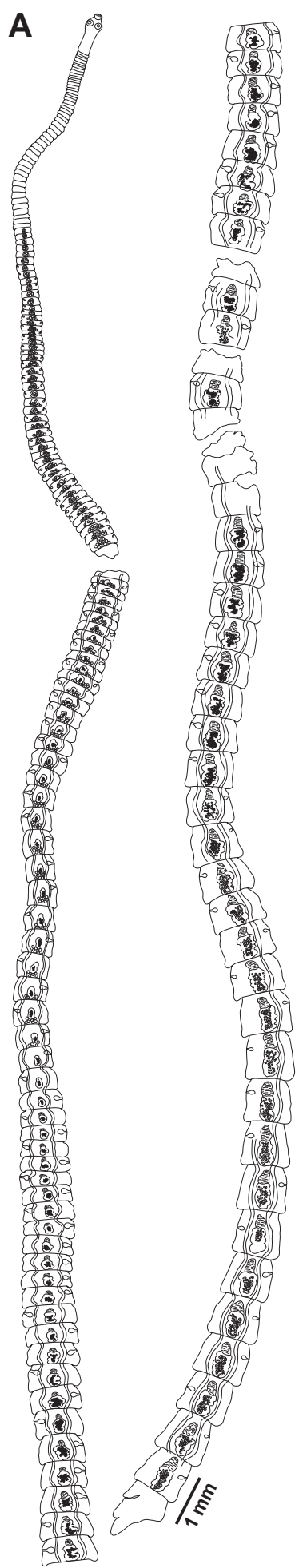

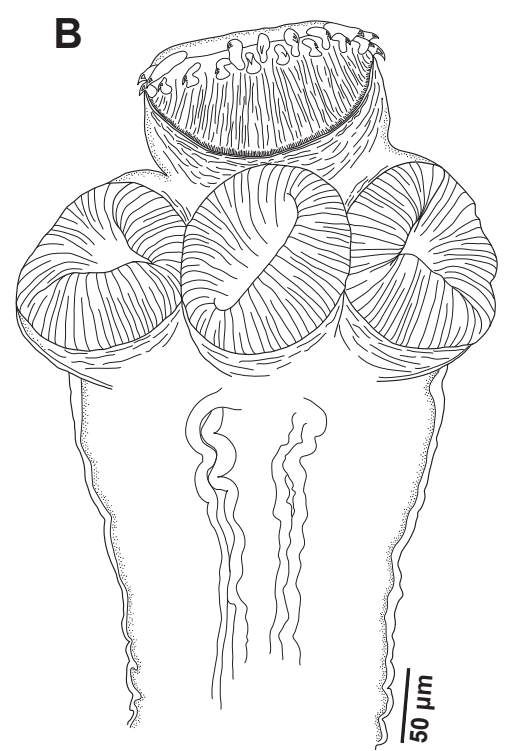

C
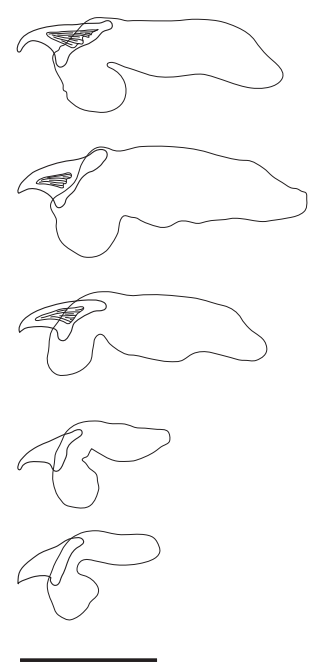

$20 \mu \mathrm{m}$
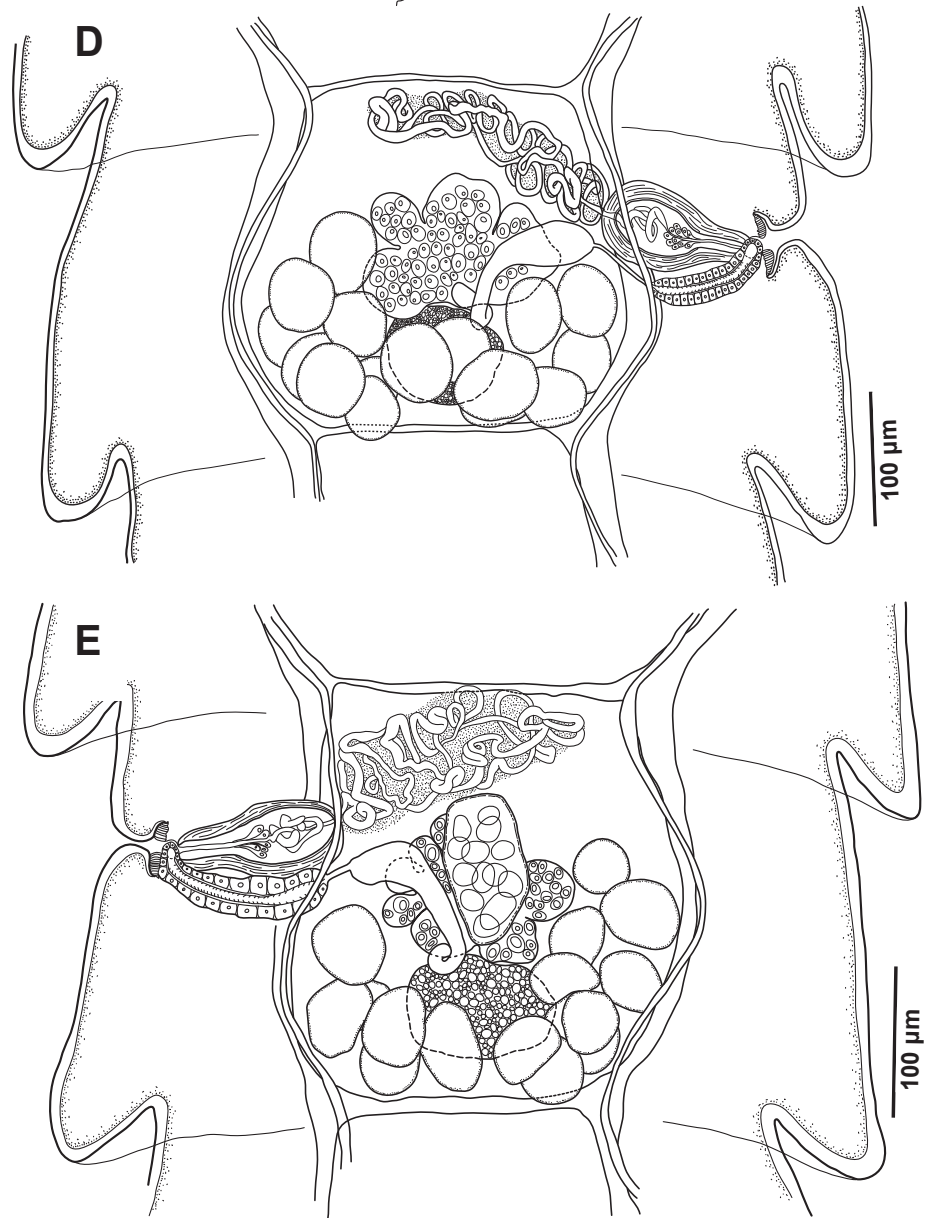

Fig. 1. Cucolepis cincta gen. n. et sp. n. A - whole worm; B - scolex; C - anterior and posterior rostellar hooks; $\mathbf{D}$ - mature proglottis; $\mathbf{E}$ - mature proglottis with developing uterus. 

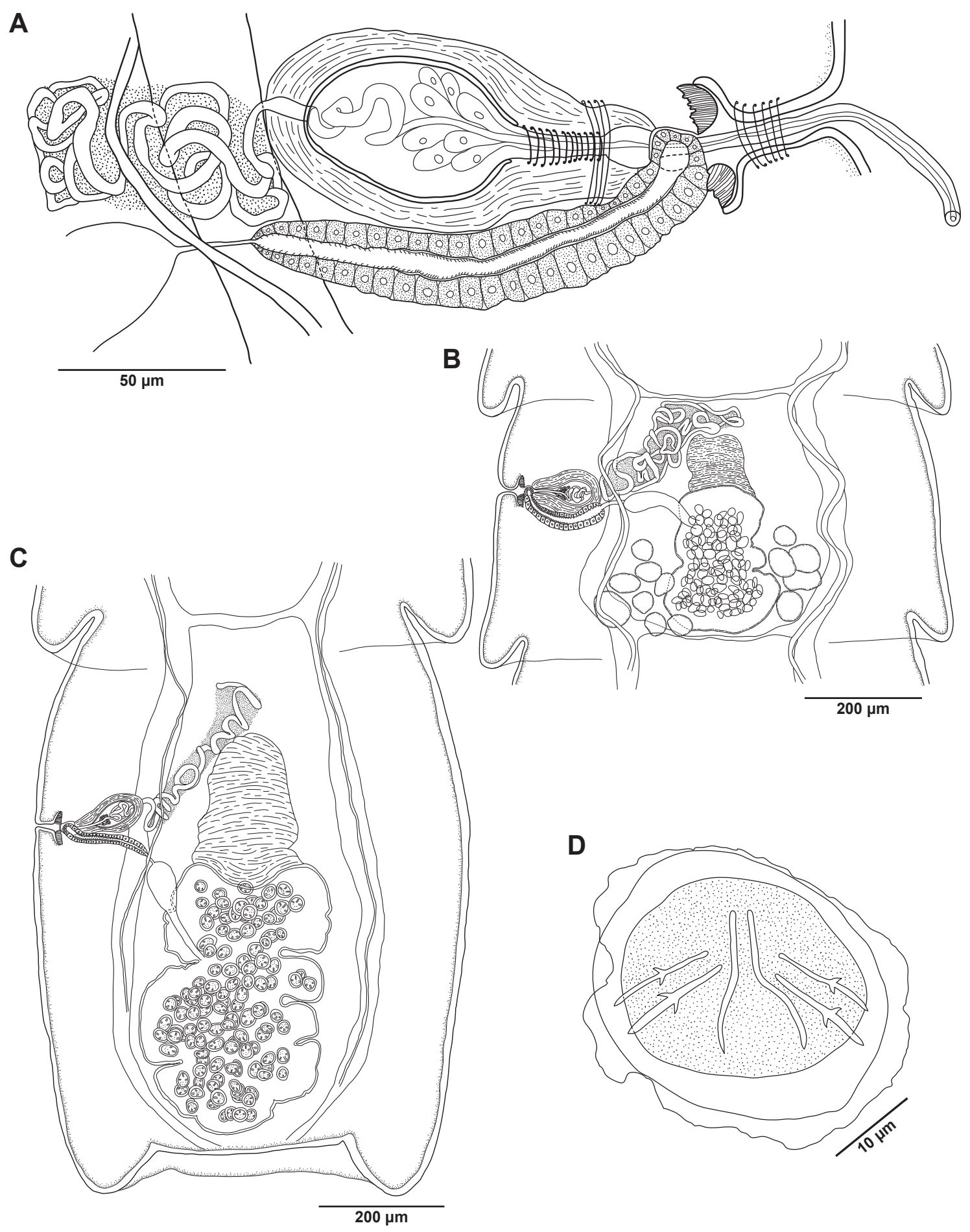

Fig. 2. Cucolepis cincta gen. n., sp. n. A - genital ducts; B - pre-gravid proglottis; C - gravid proglottis; D - egg.

Suckers round, with well-developed musculature, 111$150(129 \pm 11, \mathrm{n}=19)$ in diameter. Rostellum 129-168 $(145 \pm 16, \mathrm{n}=5)$ in diameter, sucker-like, highly muscular; glandular cells not observed within or around rostellum; well-expressed layer of radial musculature separating rostellum from surrounding parenchyma. Rostellar hooks $37-42(40 \pm 2, n=4)$ in number, arranged in one anterior and one posterior regular row, blades directed anteriorly when rostellum retracted; each hook consisting of refractive particle ("true hook") and long epiphysis comprising both handle and guard (Fig. 1C); refractive particle with short curved blade, short guard and short handle; 
epiphyses of hooks of anterior row longer than those of hooks of posterior row. Anterior rostellar hooks 36-45 ( $40 \pm 3, \mathrm{n}=10)$ long, total length of hook base including epiphyseal thickening 30-38 $(34 \pm 3, \mathrm{n}=10)$; refractive particle 6-14 $(12 \pm 3, \mathrm{n}=10)$ long, base 9-11 (10 \pm 1 , $\mathrm{n}=10)$ long, blade $6-10(7 \pm 2, \mathrm{n}=10)$ long. Posterior rostellar hooks $16-30(20 \pm 5, \mathrm{n}=8)$ long, total length of hook base including epiphyseal thickening 13-23 (17 \pm 3 , $\mathrm{n}=8)$; refractive particle $7-10(9 \pm 1, \mathrm{n}=8)$ long; base 4-7 $(6 \pm 1, \mathrm{n}=8)$ long; blade 6-7 $(6 \pm 0.4, \mathrm{n}=8)$ long. Neck short, 168-238 $(198 \pm 25, \mathrm{n}=5)$ wide. First proglottides appear at distance of 117-320 $(194 \pm 81, \mathrm{n}=5)$ from posterior margin of suckers. Genital pores irregularly alternating in short series (e.g. $1,1,1,2,1,5,1, \ldots 2$, $2,4,1,1,1,2 \ldots)$. Genital atrium with infundibular orifice and tubular middle part (Fig. 2A), thick-walled, surrounded by muscular bundles forming sphincter; basal part of atrium wider, its bottom forming thick-walled circular protrusion; short hermaphroditic canal present, containing orifices of vagina and cirrus sac. Genital ducts pass between dorsal and ventral osmoregulatory canals. Dorsal osmoregulatory canals 3-12 $(6 \pm 2, \mathrm{n}=43)$ wide. Ventral osmoregulatory canals $10-30 \quad(19 \pm 5, \mathrm{n}=40)$ wide; transverse anastomoses along posterior margin of each proglottis.

Testes spherical or slightly oval, $14-16(15 \pm 1, \mathrm{n}=9)$ in number, $30-57 \times 28-50(42 \pm 8 \times 34 \pm 5, \mathrm{n}=41$ from 14 proglottides), forming compact group situated laterally, dorsally and posteriorly to vitellarium, often slightly overlapping posterior and lateral margin of ovary (Fig. 1D). External vas deferens convoluted, surrounded by intensely staining cells, in combination forming dense body occupying anterior part of antero-medial field of proglottis. Cirrus sac pyriform (Fig. 2A), 78-152 × 35-60 $(124 \pm 19 \times 51 \pm 8, \mathrm{n}=19)$ in mature proglottides (Figs. $1 \mathrm{D}, 2 \mathrm{~A}), 118-143 \times 51-62(128 \pm 6 \times 55 \pm 3, \mathrm{n}=18)$ in post-mature and pre-gravid proglottides (Fig. 2B, C), tapering porally, rounded antiporally, thick-walled, reaching or just crossing poral osmoregulatory canals. Internal vas deferens forming several coils in antiporal part of cirrus sac (Fig. 2A). Ejaculatory duct surrounded by intensely staining cells. Evaginated cirrus cylindrical, unarmed, $42-60 \times 3-5(49 \pm 6 \times 4 \pm 1, n=6)$.

Ovary fan-shaped, medial, its width about half of median field, 80-177 $(124 \pm 24, \mathrm{n}=16)$ wide (Fig. 1D, E). Vitellarium oval, compact, medial, at some distance from posterior proglottis margin, $48-102(78 \pm 18, \mathrm{n}=16)$ in diameter. Mehlis' gland not distinct. Seminal receptacle fusiform, poral portion rounded when filled, dorsal to ovary. Vagina opening dorsal to male pore (Fig. 2A), clearly separated into copulatory and conductive parts, passing posteriorly to cirrus sac; copulatory part surrounded by thick cellular sleeve; vaginal lumen thick-walled, lined with microtriches (sometimes not distinct); conductive part short. Uterus in mature proglottides dorsal to ovary, sac-like, thick-walled, longitudinally elongate-oval. With further development in mature proglottides (Fig. 1E), uterus longitudinally elongate sac, compact or slightly lobed, occupying central part of posterior median field; primordium of paruterine organ visible as consolidation of medullary parenchyma anteriorly to uterus. Uterus in pregravid (Fig. 2B) and gravid proglottides (Fig. 2C) longitudinally elongate sac, $125-768 \times 85-343(384 \pm 193$ $\times 237 \pm 96, \mathrm{n}=30$ ); slightly lobed, occupying posterior half of median field. Paruterine organ anterior to uterus (Fig. 2B, C), almost conical, consisting of uniform fibrilar tissue. Fully gravid proglottides with eggs in paruterine organ were not observed. Eggs oval, with thin outer shell closely enveloping embryophore (Fig. 2D), 32-44 × 28$42(39 \pm 4 \times 33 \pm 4, n=15)$. Embryophore oval, 29-34 $\times$ 24-31 $(32 \pm 1 \times 26 \pm 2, \mathrm{n}=20)$, thin-walled. Oncosphere oval, $25-32 \times 18-27(28 \pm 2 \times 23 \pm 2, \mathrm{n}=20)$. Embryonic hooks: central pair thin, 14-21 $(19 \pm 2, \mathrm{n}=20)$ long; intra-lateral hooks thick, $11-16(14 \pm 1, \mathrm{n}=20)$ long; extra-lateral hooks thin, $12-16(14 \pm 1, \mathrm{n}=20)$ long.

Type host: Piaya cayana Lesson (Aves: Cuculiformes).

Type 1 ocality: Road Stroesner (Road \#7), $230 \mathrm{~km}$ from

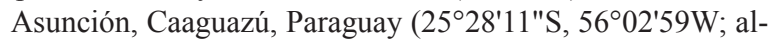
titude $300 \mathrm{~m}$ ).

Additional locality: Stream Tagatjia Guazu, $4 \mathrm{~km}$ south of the ranch Santa Maria, Concepción, Paraguay $\left(22^{\circ} 45^{\prime} 36^{\prime \prime} \mathrm{S}, 57^{\circ} 26^{\prime} 24^{\prime \prime} \mathrm{W}\right.$; altitude $\left.131 \mathrm{~m}\right)$.

Site: Small intestine.

Type material: Holotype circled in blue, MHNGPLAT-39576, collected on 13 August 1984 by C. Dlouhy; paratypes: MHNG-PLAT-82106, two specimens with scoleces and one fragment of incomplete strobila on one slide, one entire specimen with scolex and two fragments of incomplete strobila on one slide (same collection data as holotype); MHNG-PLAT-37786, three specimens with scoleces and one fragment of incomplete strobila on one slide, collected on 20 October 1985 by C. Vaucher as part of the Expeditions of the Geneva Museum in Paraguay.

E ty molog y: The meaning of "cincta" (Latin) is "surrounded". This species is named for the muscular bundles that surround and bind the genital atrium, thus forming a sphincter.

Remarks: Cucolepis cincta $\mathrm{sp}$. $\mathrm{n}$. is the only species within the genus.

\section{DISCUSSION}

Cucolepis cincta is only the fourth species of the family Paruterinidae to be described from the Cuculiformes, or cuckoos, a very diverse order in terms of habitat, social behaviour and geographic distribution. Given that paruterinids parasitize a wide diversity of avian orders, from Accipitriformes (hawks, eagles, kites and their allies) and Caprimulgiformes (nightjars), to several families of Passeriformes (perching birds), cuckoos host a relatively small portion of paruterinid diversity. Several studies have attempted to formally define the phylogenetic relationships among cuckoos using molecular, morphological, ecological and behavioural data (Hughes 1996, 2000, 2006, 
Table 1. Species of the family Paruterinidae recorded from South America.

\begin{tabular}{|c|c|c|c|c|}
\hline Cestode species & Host order & Host species & Locality & Source \\
\hline $\begin{array}{l}\text { Anonchotaenia brasiliensis } \\
\text { Fuhrmann, } 1908\end{array}$ & Passeriformes & Cacicus haemorrhous (L.) & Brazil & $\begin{array}{l}\text { Fuhrmann (1908), } \\
\text { Rausch and Morgan (1947) }\end{array}$ \\
\hline $\begin{array}{l}\text { Anonchotaenia globata } \\
\text { (von Linstow, 1879) Cohn, } 1900\end{array}$ & Passeriformes & Zonotrichia capensis (Mueller) & South America & Rausch and Morgan (1947) \\
\hline Anonchotaenia globata & Passeriformes & Sporophila caerulescens (Vieillot) & South America & Rausch and Morgan (1947) \\
\hline $\begin{array}{l}\text { Anonchotaenia macrocephala } \\
\text { Fuhrmann, } 1908\end{array}$ & Passeriformes & Progne chalybea (Gmelin) & South America & Rausch and Morgan (1947) \\
\hline Anonchotaenia macrocephala & Passeriformes & Hirundo sp. & South America & Rausch and Morgan (1947) \\
\hline Anonchotaenia macrocephala & Passeriformes & Progne tapera $(\mathrm{L})$. & South America & Rausch and Morgan (1947) \\
\hline Anonchotaenia macrocephala & Passeriformes & Progne subis (L.) & South America & Rausch and Morgan (1947) \\
\hline Anonchotaenia trochili Fuhrmann, 1908 & Apodiformes & Eupetomena macroura (Gmelin) & Brazil & Rausch and Morgan (1947) \\
\hline $\begin{array}{l}\text { Biuterina campanulata } \\
\text { (Rudolphi, 1819) Fuhrmann, } 1908\end{array}$ & Passeriformes & "Thamnophilus sulfuratus" & Brazil & Fuhrmann (1908) \\
\hline Biuterina campanulata & Passeriformes & Aphanotriccus audax (Nelson) & Brazil & Fuhrmann (1908) \\
\hline Biuterina cylindrica Fuhrmann, 1908 & Passeriformes & Tachyphonus cristatus (L.) & Brazil & Fuhrmann (1908) \\
\hline Biuterina cylindrica & Passeriformes & $\begin{array}{l}\text { "Tachyphonus melanoleucus" = Lampros- } \\
\text { piza melanoleuca (Vieillot) }\end{array}$ & Brazil & Fuhrmann (1908) \\
\hline Biuterina distincta Fuhrmann, 1908 & Passeriformes & Gracula $\mathrm{sp}$ & Brazil & Fuhrmann (1908) \\
\hline Biuterina globosa Fuhrmann, 1908 & Passeriformes & Tityra semifasciata (Spix) & Brazil & Fuhrmann (1908) \\
\hline $\begin{array}{l}\text { Biuterina motacillacayanae } \\
\text { (Rudolphi, 1819) Fuhrmann, } 1908\end{array}$ & Passeriformes & Dacnis cayana $(\mathrm{L})$. & Brazil & Fuhrmann (1908) \\
\hline Biuterina trapezoides Fuhrmann, 1908 & Passeriformes & Emberiza sp. & Brazil & Fuhrmann (1908) \\
\hline Biuterina trapezoides & Passeriformes & $\begin{array}{l}\text { "Molothrus peconis" = Molothrus ater } \\
\text { (Boddaert) }\end{array}$ & Brazil & Fuhrmann (1908) \\
\hline Biuterina trapezoides & Caprimulgiformes & Caprimulgus sp. & Brazil & Fuhrmann (1908) \\
\hline $\begin{array}{l}\text { Biuterina trigonacantha } \\
\text { Fuhrmann, } 1908\end{array}$ & Passeriformes & Schoeniophylax phryganophilus (Vieillot) & Brazil & Fuhrmann (1908) \\
\hline $\begin{array}{l}\text { Cucolepis cincta gen. n. et sp. n. } \\
\text { Phillips, Georgiev et Mariaux, } 2012\end{array}$ & Cuculiformes & Piaya cayana (L.) & Paraguay & Present study \\
\hline Culcitella bresslaui Fuhrmann, 1927 & Accipitriformes & Buteo leucorrhoea (Quoy et Gaimard) & Brazil & Fuhrmann (1927) \\
\hline Culcitella crassa Fuhrmann, 1906 & Accipitriformes & Spizaetus ornatus (Daudin) & Brazil & Fuhrmann (1906) \\
\hline Culcitella rapacicola Fuhrmann, 1906 & Accipitriformes & Ictinia plumbea Gmelin & Brazil & Fuhrmann (1906) \\
\hline Culcitella rapacicola & Accipitriformes & Geranospiza caerulescens (Vieillot) & Brazil & Fuhrmann (1906) \\
\hline Culcitella rapacicola & Accipitriformes & Buteo nitidus (Latham) & Brazil & Fuhrmann (1906) \\
\hline $\begin{array}{l}\text { Francobona similis (Ransom, 1909) } \\
\text { Georgiev et Kornyushin, } 1994\end{array}$ & Cuculiformes & Coccyzus melacoryphus Vieillot & Argentina & Bona and Maffi (1985) \\
\hline $\begin{array}{l}\text { Francobona similita (Bona et Maffi, } \\
\text { 1984) Georgiev et Kornyushin, } 1994\end{array}$ & Cuculiformes & Coccyzus melacoryphus & Argentina & Bona and Maffi (1984a) \\
\hline Francobona similita & Cuculiformes & Coccyzus merlini D’Orbigny & Argentina & Bona and Maffi (1984a) \\
\hline Francobona similita & Cuculiformes & Piaya cayana & Argentina & Bona and Maffi (1984a) \\
\hline Laterotaenia natteri Fuhrmann, 1906 & Accipitriformes & Sarcoramphus papa (L.) & Brazil & Fuhrmann (1906) \\
\hline Orthoskrjabinia sp. & Passeriformes & Paroaria coronata (Miller) & Brazil & Mascarenhas et al. (2009) \\
\hline Paruterina angustata Fuhrmann, 1906 & Strigiformes & "Scotopelia brasilianus" & Brazil & von Linstow (1906) \\
\hline Paruterina otidis Baczynska, 1914 & Strigiformes & Asio flammeus (Pontoppidan) & Brazil & Baczynska (1914) \\
\hline $\begin{array}{l}\text { Paruterina trogoni } \\
\text { Bona, Bosco et Maffi, } 1986\end{array}$ & Trogoniformes & Trogon rufus Gmelin & Peru & Bona et al. (1986) \\
\hline $\begin{array}{l}\text { Parvirostrum linusi } \\
\text { Georgiev et Vaucher, } 2001\end{array}$ & Passeriformes & Dendrocolaptes platyrostris Spix & Paraguay & $\begin{array}{l}\text { Georgiev and Vaucher } \\
(2001)\end{array}$ \\
\hline $\begin{array}{l}\text { Parvirostrum recticulatum } \\
\text { Fuhrmann, } 1908\end{array}$ & Passeriformes & Lepidocolaptes albolineatus (Lafresnaye) & Brazil & Fuhrmann (1908) \\
\hline Parvirostrum reticulatum & Passeriformes & Xiphorhynchus elegans (Pelzeln) & Brazil & Fuhrmann (1908) \\
\hline Parvirostrum reticulatum & Passeriformes & Xiphorhynchus guttatus Lichtenstein & Brazil & Fuhrmann (1908) \\
\hline Parvirostrum sp. & Passeriformes & Lepidocolaptes angustirostris (Vieillot) & Paraguay & $\begin{array}{l}\text { Georgiev and Vaucher } \\
\text { (2001) }\end{array}$ \\
\hline $\begin{array}{l}\text { Parvirostrum synallaxis (Mahon, 1957) } \\
\text { Georgiev et Vaucher, } 2001\end{array}$ & Passeriformes & Synallaxis rutilans Temminck & Brazil & Mahon (1957) \\
\hline $\begin{array}{l}\text { Sphaeruterina fuhrmanni } \\
\text { (Baczyncka, 1914) Fuhrmann, } 1932\end{array}$ & Piciformes & Bucco sp. & Brazil & Baczynska (1914) \\
\hline $\begin{array}{l}\text { Sphaeruterina longiceps } \\
\text { (Rudolphi, 1819) Fuhrmann, } 1932\end{array}$ & Passeriformes & Cacicus haemorrhous (L.) & Brazil & Rudolphi (1819) \\
\hline Sphaeruterina longiceps & Passeriformes & Psarocolius decumanus (Pallas) & Brazil & Rudolphi (1819) \\
\hline $\begin{array}{l}\text { Troguterina disparhamulis (Bona, Bo- } \\
\text { sco et Maffi, 1986) Spasskii, } 1991\end{array}$ & Trogoniformes & Trogon violaceus Gmelin & Peru & Bona et al. (1986) \\
\hline $\begin{array}{l}\text { Troguterina disparuncinata (Bona, } \\
\text { Bosco et Maffi, 1986) Spasskii, } 1991\end{array}$ & Trogoniformes & Trogon curucui (L.) & Argentina & Bona et al. (1986) \\
\hline
\end{tabular}


Johnson et al. 2000, Posso and Donatelli 2006, 2010). The most robust available phylogeny for the cuckoos is that of Sorenson and Payne (2005), which was based on an exhaustive sampling of extant cuckoo species and an extensive mitochondrial dataset. Their analysis confirmed the monophyly of the Cuculiformes and its organization into five subfamilies: Crotophaginae (anis), Neomorphinae (New World ground cuckoos), Centropodinae (coucals), Couinae (Malagasy couas and Southeast Asian ground cuckoos), and Cuculinae (arboreal cuckoos). Over half of known cuckoo species fall within the Cuculinae, the only subfamily to be further divided into tribes: Cuculini (Old World brood parasitic cuckoos) and Phaenicophaeni (malkhoas of the Old World and New World "coccyzine cuckoos"). Recent molecular phylogenetic work supports the "coccyzine cuckoos" as monophyletic and to include the three genera Coccycua Lesson, Coccyzus Vieillot and Piaya, with Coccycua being the basal lineage of the clade (Sorenson and Payne 2005, Hughes 2006).

In addition to $C$. cincta, five species (including three undescribed) of the cestode family Paruterinidae have been reported from "coccyzine cuckoos": Francobona similis (Ransom, 1909) Georgiev et Kornyushin, 1994, Francobona similita (Bona et Maffi, 1984) Georgiev et Kornyushin, 1994, two undescribed species within the "rectangula" group of Paruterina Fuhrmann, 1906 (sensu Bona and Maffi 1984a) and an unidentified species (see Bona and Maffi 1984a, b) of Triaenorhina. Coccycua is the only genus of the group for which members have not been examined yet for cestodes. To our knowledge, paruterinids are mostly stenoxenous, i.e. they do not exhibit strict host specificity of one cestode species parasitizing a single host species, but rather paruterinid species can be found in several phylogenetically related species of hosts. Given that the morphology of $C$. cincta is most similar to that of Francobona spp. and the phylogenetic relationships of the hosts of these species, it would not be surprising to find paruterinid species, including species of Cucolepis or Francobona, parasitizing individuals of Coccycua.

Cuckoos also host cestodes of two other cyclophyllidean families. At least three species of dilepidids have been reported from two species of Crotophaginae and three species representing both tribes of the Cuculinae (see Fuhrmann 1907, Macko and Rysavy 1982, Mariaux and Vaucher, 1990). At least five species of davaineids have been reported from Centropodinae (see Southwell 1922). However, each of these cestode families contains more than 300 species and cuckoos host a remarkably small proportion of that diversity. Neomorphinae and Couinae are the only subfamilies remaining of Cuculiformes that currently lack cestode records.

It is tempting to look for a pattern in the absence of cestode records from these two cuculiform subfamilies. For example, it may appear to be connected to host habitat given that species of these two subfamilies are predominately ground-dwelling, although both subfamilies include some arboreal species (Sorenson and Payne 2005). That having been said, there are records of members of other cestode families parasitizing ground-dwelling birds, such as davaineids in tinamous (Fuhrmann 1909). It is critical to determine if the relative scarcity, or complete lack, of cestode records from members of the Cuculiformes speaks to inadequate sampling throughout the host order, to any resulting cestode diversity not having been recognized or studied, or possibly to the actual absence of cestodes from those potential hosts.

In general, the records of paruterinids from South America are spotty and scattered across several orders of birds (Table 1). The bulk of paruterinid species reported from South America derives from descriptions published between 1906 and 1947, often with imprecise localities, such as simply "South America" or "Brazil" (Fuhrmann 1906, 1908, 1927, Rausch and Morgan 1947). This makes new collections of paruterinids in South America interesting because of the high potential to be either new locality or host records or to provide new material for comparative analyses based on morphological or molecular data.

Acknowledgements. We are grateful to Carlos Dlouhy and Claude Vaucher for collecting the specimens. We thank Janine Caira for her continual support. Janine Caira and two anonymous referees are acknowledged for their constructive comments on this manuscript. This work was funded by the National Science Foundation, PBI grants DEB 0818696 and DEB 0818823.

\section{REFERENCES}

BACZynska H. 1914: Etudes anatomiques et histologiques sur quelque nouvelles espèces de Cestodes d'oiseaux. Bull. Soc. Neuchâtel. Sci. Nat. 40: 187-239.

Bona F.V., Bosco M.C., Maffi A. 1986: Tre nuove specie del genera Paruterina (Cestoda, Paruterinidae) in Trogoniformi (Aves) neotropicali. Boll. Mus. Reg. Sci. Nat. 4: 1-61.

Bona F.V., Maffi A.V. 1984a: La estructura del género Paruterina Fuhrm., 1906 y consideraciones sobre los géneros Biuterina Fuhrm., 1902, Proparuterina Fuhrm., 1911 y Sphaeruterina Johnston, 1914 (Cestoda, Paruterinidae). Mus. Reg. Sci. Nat. Boll. (Torino) 2: 411-443.
Bona F.V., Maffi A.V. 1984b: Paruterina similita n. sp. (Cestoda, Paruterinidae) en Cuculidae (Aves) del Norte de Argentina. Mus. Reg. Sci. Nat. Boll. (Torino) 2: 181-198.

Bona F.V., Maffi A.V. 1985: Redescripción y variabilidad de Paruterina similis (Ransom, 1909) (Cestoda, Paruterinidae), recolectada en un neuvo hospedador, Coccyzus melacoryphus (Cuculiformes) en el norte de Argentina. Riv. Parassitol. 2 (46): 115-139.

Bona F.V., Maffi A.V. 1987: Los Paruterinidae (Cestoda) con ganchos de patron "rectanguloide". Parte I. Observaciones sobre los ganchos rectanguloides y revisión de la literatura. Boll. Mus. Reg. Sci. Nat. 5: 455-489. 
Fuhrmann O. 1906: Die Taenien der Raubvögel. Zbl. Bakt. Hyg. I. Abt. Orig. 41: 440-452.

Fuhrmann O. 1907: Bekannte und neue Arten und Genera von Vogeltänien. Zbl. Bakt. Hyg. I. Abt. Orig. 45: 516-536.

Fuhrmann O. 1908: Nouveaux taenias d'oiseaux. Rev. Suisse Zool. 16: 27-73.

Fuhrmann O. 1909: Neue Davaineiden. Zbl. Bakt. Hyg. I. Abt. Orig. 49: 94-124.

Fuhrmann O. 1927: Brasilianische Cestoden aus Reptilien und Vogeln. Abh. Senckenb. Naturforsch. Ges. 40: 389-401.

Georgiev B.B., Gibson D.I. 2006: Description of Triaenorhina burti n. sp. (Cestoda: Paruterinidae) from the Malabar trogon Harpactes fasciatus (Pennant) (Aves: Trogoniformes: Trogonidae) in Sri Lanka. Syst. Parasitol. 63: 53-60.

Georgiev B.B., Kornyushin V.V. 1994: Family Paruterinidae Fuhrmann, 1907 (sensu lato). In: L.F. Khalil, A. Jones and R.A. Bray (Eds.), Keys to the Cestode Parasites of Vertebrates. CAB International, Wallingform, UK, pp. 559-584.

Georgiev B.B., Vaucher C. 2001: Revision of the genus Parvirostrum Fuhrmann, 1908 (Cestoda: Cyclophyllidea: Paruterinidae). Syst. Parasitol. 50: 13-29.

Gill F., Donsker D. (Eds.) 2012: IOC World Bird Names (v. 2.11). Available at http://www.worldbirdnames.org/ [Accessed $13 / 2 / 2012]$

Hughes J.M. 1996: Phylogenetic analysis of the Cuculidae (Aves, Cuculiformes) using behavioral and ecological characters. The Auk 113: 10-22.

Hughes J.M. 2000: Monophyly and phylogeny of cuckoos (Aves, Cuculidae) inferred from osteological characters. Zool. J. Linn. Soc. 130: 263-307.

Hughes J.M. 2006: Phylogeny of the cuckoo genus Coccyzus (Aves: Cuculidae): a test of monophyly. Syst. Biodiv. 4: 483488.

Johnson K.P., Goodman S.M., Lanyon S.M. 2000: A phylogenetic study of the Malagasy couas with insights into cuckoo relationships. Mol. Phylogenet. Evol. 14: 436-444.

von Linstow O.F.B. 1906: Helminthes from the collection of the Columbo Museum. Spolia Zeylanica 3: 163-188.

MACKO J.K., RYŠAVÝ B. 1982: Vitta crotophagae sp. n. (Cestoda: Dilepididae), a new cestode species from Crotophaga ani L. in Cuba. Folia Parasitol. 29: 297-301.
Maноn J. 1957: Deltokeras synallaxis sp. nov. (Dilepididae) from Synallaxis rutilans Temm. Can. J. Zool. 35: 441-447.

Mariaux J., Vaucher C. 1990: A new genus of Dilepididae (Cestoda) of the yellowbill Ceuthmochares aereus (Cuculidae) from the Ivory Coast. J. Parasitol. 76: 22-26.

Mascarenhas C.S., Kreuger C., Meuller G. 2009: The helminth fauna of the red-crested cardinal (Paroaria coronata) Passeriformes: Emberizidae in Brazil. Parasitol. Res. 105: 1359-1363.

Posso S.R., Donatelli R.J. 2006: Análise filogenética e implicações sistemáticas e evolutivas nos Cuculiformes (Aves) com base na osteologia, comportamento e ecologia. Rev. Bras. Zool. 23: 608-629.

Posso S.R., Donatelli R.J. 2010: When decisions on homologous structures cause ambiguous taxa relationships: the Neomorphinae (Aves, Cuculidae) example. Braz. J. Biol. 70: 195-204.

Rausch R.L., Morgan B.B. 1947: The genus Anonchotaenia (Cestoda: Dilepididae) from North American birds, with the description of a new species. Trans. Am. Microsc. Soc. 66: 203-211.

RudolPhi C.A. 1819: Entozoorum Synopsis cui Accedunt Mantissa Duplex et Indices Locupletissimi. Sumtibus Augusti Ruecker, Berlin, $811 \mathrm{pp}$.

Scholz T., Kuchta R., Salgado-Maldonado G. 2002: Cestodes of the family Dilepididae (Cestoda: Cyclophyllidea) from fisheating birds in Mexico. Syst. Parasitol. 52: 171-182.

Sorenson M.D., Payne R.B. 2005: Molecular systematics: cuckoo phylogeny inferred from mitochondrial DNA sequences. In: R.B. Payne (Ed.), Bird Families of the World: Cuckoos. Oxford University Press, New York, USA, pp. 68-94.

Southwell T. 1922: Cestodes from Indian birds with a note on Ligula intestinalis. Ann. Trop. Med. Parasitol. 16: 355-382.

Spasskil A.A., Shumilo R.P. 1965: [The phenomenon of the postlarval development of the rostellum and the hooks in the cestodes of the genus Triaenorhina, n. gen. (Paruterinidae).]. Doklady Akademii Nauk SSSR 164: 1436-1438. (In Russian).

Vasileva G.P., Georgiev B.B., Genov T. 2000: Palaearctic species of the genus Confluaria Ablasov (Cestoda, Hymenolepididae): redescriptions of C. podicipina (Szymanski, 1905) and C. furcifera (Krabbe, 1869), description of C. pseudofurcifera n. sp., a key and final comments. Syst. Parasitol. 45: 109-130. 